\title{
Transformation of a lowland river from a meandering and multi-channel pattern into an artificial canal: retracing a path of river channel changes (the Middle Obra River, W Poland)
}

\author{
Marcin Słowik
}

Received: 24 November 2011/ Accepted: 23 March 2013/Published online: 5 April 2013

(C) The Author(s) 2013. This article is published with open access at Springerlink.com

\begin{abstract}
At the beginning of the nineteenth century, a significant change in sedimentation took place along the middle course of the Obra River (W Poland): a "natural" channel bed was replaced by three artificial canals. Before that time the Obra River bed had been characterized by various river patterns (braided, meandering and disappearing in wetlands). GPR (ground-penetrating radar) surveys and the analysis of satellite and aerial images were carried out to retrace the natural river course near the village of Kopanica. The GPR, ground-truthed with core data, revealed that at least two types of the river pattern had been functioning here before the period of the hydrotechnical works: a large-scale meandering pattern (width-to-depth $(w / d)$ ratio ranging from 15 to 40$)$ and a relatively smallerscale multi-channel pattern $(w / d=11-22)$. Possibly, the transformation was caused by forming a series of large floods followed by in-channel aggradation and avulsions. Next, the multi-channel pattern was artificially transformed into the North Obra Canal. This paper discusses possibilities of a creation of network of channels that were active after the construction of the North Obra Canal in the beginning of the nineteenth century. Such intervention would increase natural values of the presented section of the Obra valley. The presented study also shows that a detailed analysis of history and evolution of a given river course is needed before undertaking any restoration works.
\end{abstract}

Keywords Changes of river bed pattern - Anthropogenic intervention · Ground-penetrating radar · River restoration

\section{Słowik ( $\square)$}

Department of Geographic and Geologic Sciences,

Adam Mickiewicz University, ul, Dzięgielowa 27,

61-680 Poznan, Poland

e-mail: slowik@amu.edu.pl

\section{Introduction}

An analysis of the state of human-modified rivers strongly depends on the ability to reconstruct the natural form and functioning of a given river basin. Such information may be a useful guide for river managers in case of planning a restoration project (Hoffmann et al. 2010). In some cases, river courses were modified by an anthropogenic intervention in such a way that it is impossible to discern humaninduced changes from the natural state. There are many examples of transformation of natural river bed patterns into artificial canals (e.g., the Trent River: Large and Petts 1996; the Morava River: Babek et al. 2008). Another type of human intervention was construction of mills (e.g., Large and Petts 1996; the Obra River, Kaniecki 2004; Kaniecki and Brychcy 2010) and dams in river courses (e.g., the Dry Creek: Gordon and Meetenmeyer 2006). Rivers were also regulated aiming to stabilize a river bed (e.g., the Danube River: Gingrich et al. 2011). Analyses of river bed pattern changes are usually conducted using historical materials (e.g., Large and Petts 1996; Gingrich et al. 2011; WoelfleErskine et al. 2012) and data from field research. Conventional field studies (coring and trenching, collecting sediment samples or cores to recognize lithology of an alluvial fill) are also used to study both natural and anthropogenic changes of river patterns.

This paper aims to reconstruct the "natural" (functioning before the major hydrotechnical works) course of a lowland river (the Obra River, W Poland; Fig. 1) by means of geophysical (ground-penetrating radar (GPR)) surveys and the analysis of satellite and aerial images. It is a continuation of studies conducted in the Middle Obra valley by Słowik (2011a, 2013). It presents the results of a field research carried out in the area where traces of former river beds were preserved in the modern land surface (Fig. 2c, d). The previous 
research works in the Middle Obra valley indicated remains of one (multi-channel) pattern that had been active before the construction of the canals. In this case, traces of two different river platforms were discovered (meandering and multichannel). This provided an opportunity to study the evolution of the Middle Obra River including factors that may have influenced the transformation of the river pattern. Secondly, this paper shows a potential to study the river pattern changes in a longer timescale; it characterizes not only the multichannel planform recognized in the other parts of the valley, but also a meandering pattern that may have been active before the transition.

Moreover, discovering remains of two different river patterns active in the past in one site provokes a discussion: Which of the river patterns should be restored? This study underlines the use of geophysical and remote sensing methods supported by core data for river restoration and the importance of knowledge regarding postglacial evolution of rivers that should be used by river restoration engineers. It is proposed to create a multi-channel course similar to conditions from the first half of the nineteenth century. Possibilities of the creation are discussed showing a path of past changes as well as creation steps to achieve the planned target. Both natural and anthropogenic transformations of the Obra River bed pattern are discussed taking also into account information inferred from archival maps, GPR measurement ground-truthed with core data (illustrating sedimentary structures of a shallow subsurface) and remote sensing surveys (showing traces of former river beds in the land surface).

\section{Study area}

The Obra River valley is situated in the middle and western part of Poland (Fig. 1) in the area formed by the Vistulian glaciation 15,000-20,000 years ago. Its middle course was formed in fluvioglacial deposits within the Warsaw-Berlin proglacial stream valley. The Obra valley fill is built of alluvial sands, peats and muds (Multan 2003). The river is $253 \mathrm{~km}$ long, and its drainage area is $4,022 \mathrm{~km}^{2}$. It has two natural outlets: to the Odra River (a canalized bifurcation of the Obra River; Fig. 1) and to the Warta River (Fig. 1). In its middle course, the Obra has also one artificial connection with the Warta River (the Mosiński Canal; Fig. 1).

The first hydrotechnical constructions (water mills) were built in the Middle Obra valley in the twelfth century (Kaniecki and Brychcy 2010). However, the major hydrotechnical works were conducted here in the beginning of the nineteenth century; three artificial canals were constructed in the middle course of the river (the North, the Middle and the South Obra Canal; Fig. 1). The canals replaced the natural river course characterized by various patterns (meandering, multi-channel and disappearing in wetlands; Słowik 2011a) and influenced changes of spatial extent of lakes situated in the course of the river (Słowik 2013). According to Dynowska (1972), hydrological regime of the Obra River is temperate with spring floods and groundwater-rainfall water supply.

The detailed study site is situated next to the North Obra Canal, near the village of Kopanica (Fig. 2). It is located close to the bifurcation to the Odra River (Fig. 1) -also

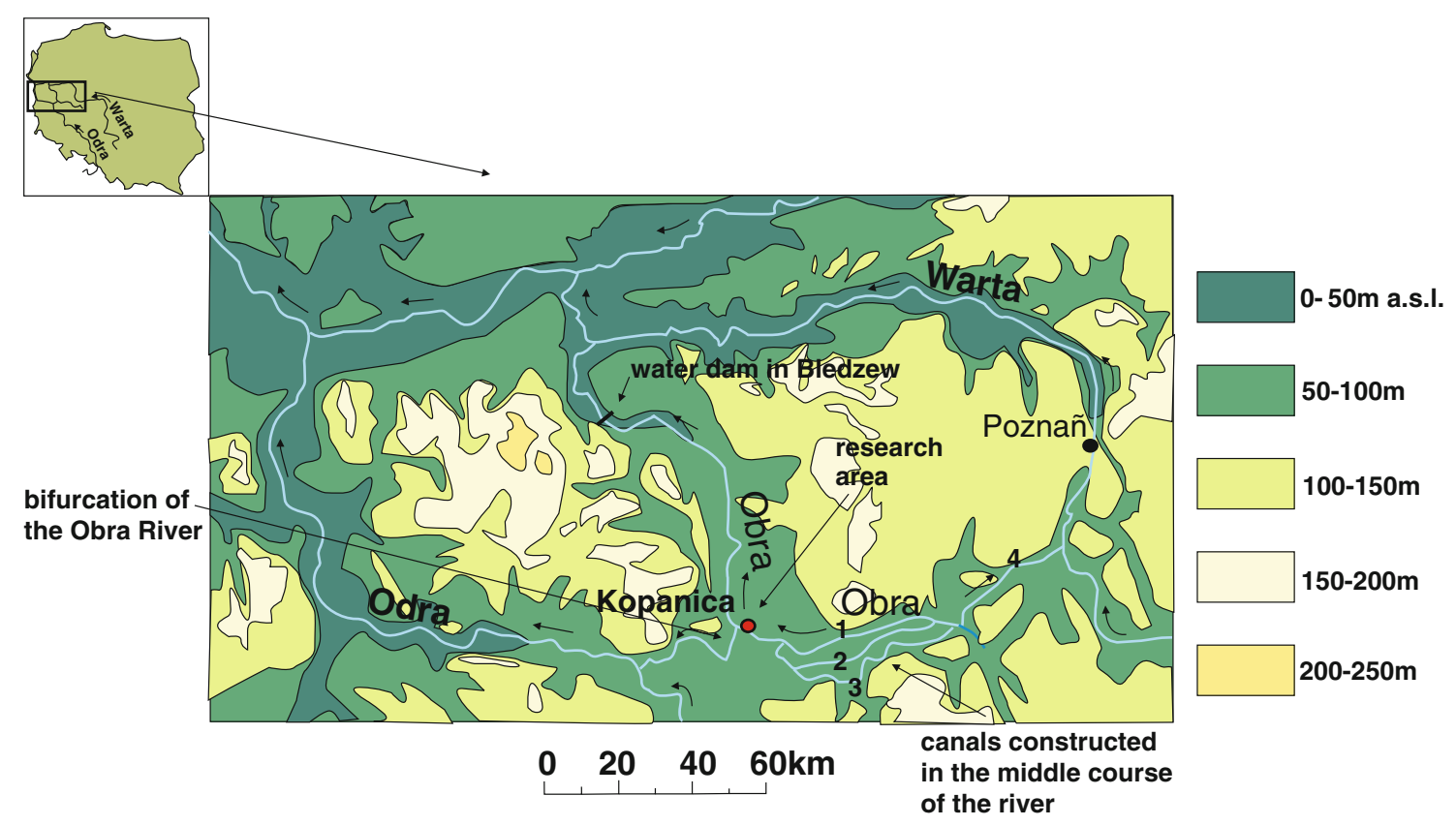

Fig. 1 The middle and lower course of the Obra River. 1-the North Obra Canal, 2-the Middle Obra Canal, 3-the South Obra Canal, 4-the Mosiński Canal 


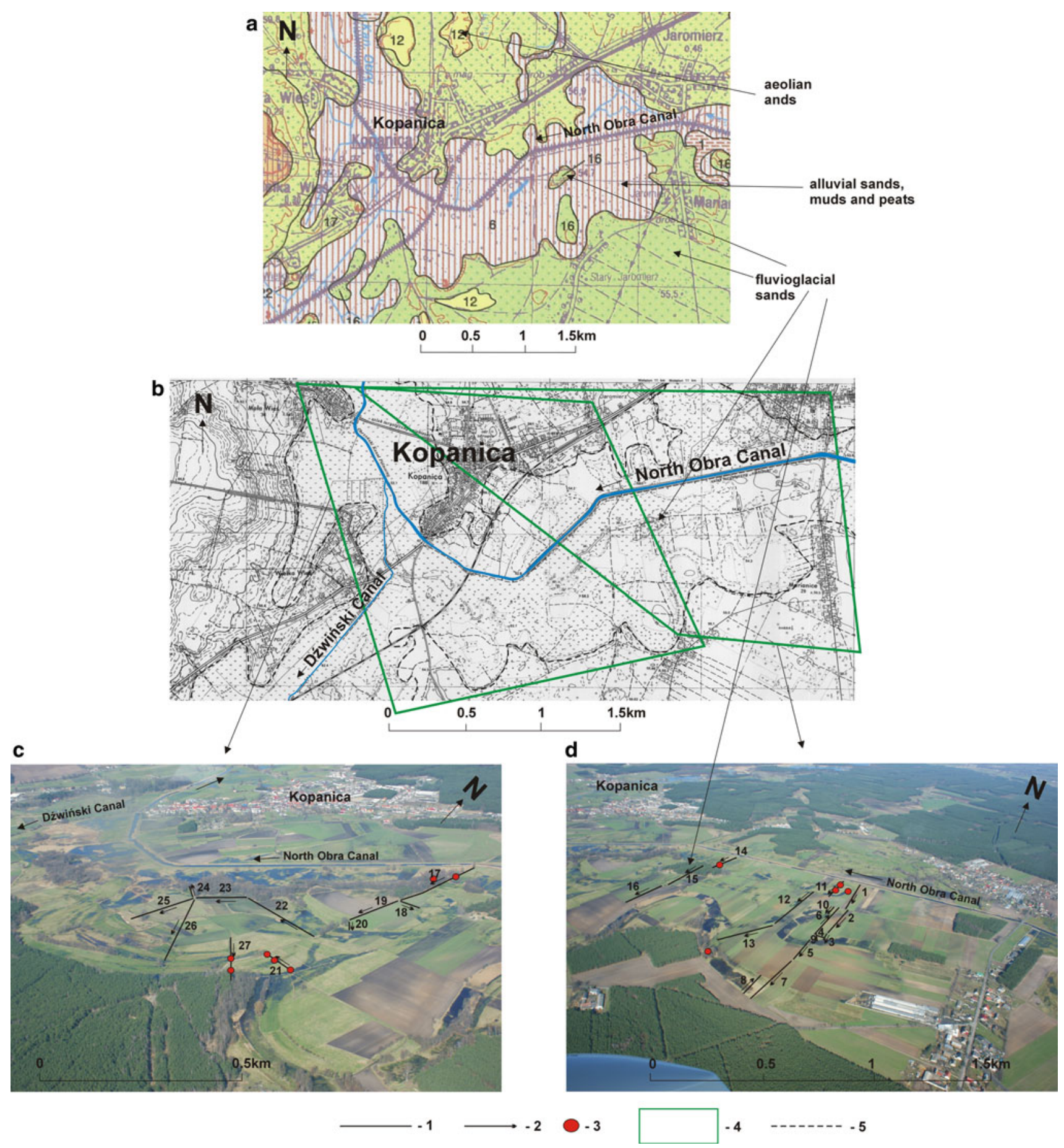

Fig. 2 Surface sediments geologic map (Multan 2003) a topographic map b aerial images c, d detailed research area. 1-GPR sections, 2-direction of measurement, 3-places of coring, 4-the area illustrated in aerial images, 5-edge of the valley

transformed into an artificial canal (the Dźwiński Canal; Fig. 2). The site was chosen for a detailed analysis due to a complex river pattern that had been functioning here before the period of the hydrotechnical works. Moreover, distinct traces of river channels preserved in the modern land surface were localized in aerial photographs (Fig. 2c, d). The width of the studied section of the valley varies from 0.5 to
$1.6 \mathrm{~km}$ (Fig. 2). Traces of a discontinuous terrace level can be found in the valley floor. The Obra valley is an agricultural area; corn is the main sort of cultivation.

Historical maps show that the Obra River bed had a multi-channel pattern in the eighteenth century (Kopanica was called "Kobenitz" or "Kopnitz" at that time; Fig. 3a). In 1828, the North Obra Canal was still connected with the 
network of channels (Fig. 3b). The remains of the multichannel pattern stopped functioning before the end of the nineteenth century (Fig. 3c); single fragments of the channels can be seen east of the village of Mariendorf (the map from 1892; Fig. 3c). The North Obra Canal is secured with artificial dikes acting as flood protection. In summer season, the Canal is overgrown with vegetation and surface water velocities do not exceed $0.3 \mathrm{~m} \mathrm{~s}^{-1}$. They increase to $1.0 \mathrm{~m} \mathrm{~s}^{-1}$ at early spring during high water levels caused by snow meltout. Meadows and agricultural areas surrounding the Canal are inundated at that time owing to high groundwater levels and the lack of amelioration ditches. The river course is rarely used by tourist (canoe trips) due to the overgrowth, straight course and the dikes that block views of the landscape.

\section{Research methods}

The GPR surveys were conducted using a georadar MALA ProEx equipped with shielded 100 and $250 \mathrm{MHz}$ antennae to retrace the natural course of the Obra River. GPR is a nondestructive geophysical technique that enables a nearcontinuous record of sedimentary structures in the shallow subsurface. During the measurement, the equipment transmits a high-frequency electromagnetic wave. Contrasts in the dielectric constant usually cause strong reflections from lithologic boundaries in the subsurface. The frequency of georadar antennae decides on the depth range and resolution of measurement. In general, the higher the antenna frequency, the finer the resolution and the shallower the depth range is (Neal 2004). A detailed characteristic of the use of GPR technique in sedimentology was presented by Neal (2004).

The GPR surveys were conducted in August 2011 along 27 profile lines (Fig. 2). Situation of the lines was conditioned by traces of former channels preserved in the land surface but also by high groundwater level (some depressions were inundated and inaccessible) and cultivation. During the conducted measurement, depths of penetration reached from $2.4 \mathrm{~m}$ b.l.s. (below the land surface; $250 \mathrm{MHz}$ antenna) to $3.7 \mathrm{~m} \mathrm{~b}$ b.s. (100 MHz antenna). Groundwater level varied from about $0-0.1 \mathrm{~m} \mathrm{~b}$ b.s. in depression to $0.5 \mathrm{~m}$ b.l.s. in elevated parts of the GPR profile lines. The measurement was triggered at constant spacings $(0.2 \mathrm{~m})$ by an odometer wheel.

The GPR images were processed using ReflexW5.0 software. Subtract-mean (dewow) filter was used to eliminate low-frequency noise. Bandpass frequency tool enabled to eliminate disturbances occurring at the high and low ends of the spectrum of GPR signal amplitudes (Best et al. 2006). Low-amplitude reflections were enhanced using AGC gain. Background removal filter was applied to remove horizontal banding that appeared across particular GPR sections. Static correction tool was used for elevation corrections where necessary.

The depth range of the GPR measurement was determined by a comparison of distinct georadar reflectors appearing in the GPR images and core data. Twelve boreholes were drilled to determine the georadar depth range and recognize lithology of the Obra valley alluvial fill. The profiles with boreholes were treated as reference sites for interpretation of all the GPR images. In case of a borehole in $52 \mathrm{~m}$ GPR section 11, a distinct GPR reflector corresponded well to the interface between peats and fine sands at the depth of $1.4 \mathrm{~m}$ b.1.s. (Fig. 5). Such a procedure was also applied to the remaining core data (Figs. 4, 5). A similar way of determining the depth range of GPR measurement was presented by, for example, Skelly et al. (2003). For the brevity of the paper, six chosen GPR sections representing the most important features of the floodplain architecture were presented (Figs. 5, 6).

The situation of the traces of river channels in the modern land surface was determined using aerial and satellite images. The aerial survey was conducted on the $1 \mathrm{st}$ of April 2010. It was possible to study the configuration of the Obra valley floor as the land surface was not covered with vegetation yet. Moreover, the survey was carried out in a period of high water stages. All the depressions in the valley floor were easy to distinguish as they were inundated. The height of the survey was from 100 to $300 \mathrm{~m}$. The oblique photographs were taken using a camera Sony $\alpha 350$. The angle of taking the photos was $\sim 10^{\circ}$ with horizon and $\sim 40^{\circ}$ without horizon. The resolution of the pictures was 14.2 megapixels. Furthermore, orthorectified LANDSAT ETM+ images were analyzed. The dataset from the 13 June 2000 (path 191, row 024) was downloaded from http://landsat.org Web site (Global Observatory for Ecosystem Services, Michigan State University). The images were processed in ArcGIS9.3.1 software to analyze traces of the river channels in the floodplain's surface. The best image for interpretation was produced by combining bands 5, 4, 2 and 8 (panchromatic image) and applying a pansharpening option to increase the resolution of the image.

Historical maps from 1775, 1793, 1828 and 1892 were analyzed to study anthropogenic changes of the river bed pattern and the land use. The earliest maps presented here are featured with a low accuracy as the distances between, for example, towns or villages were not maintained. The materials provide general information how the Obra River looked like in the vicinity of a given village. The maps from the nineteenth century were edited in 1:25,000 scale. They were edited by the General Staff of the Prussian Army. The maps were made on the basis of triangulation measurement, and their accuracy is comparable with the modern maps. 
a

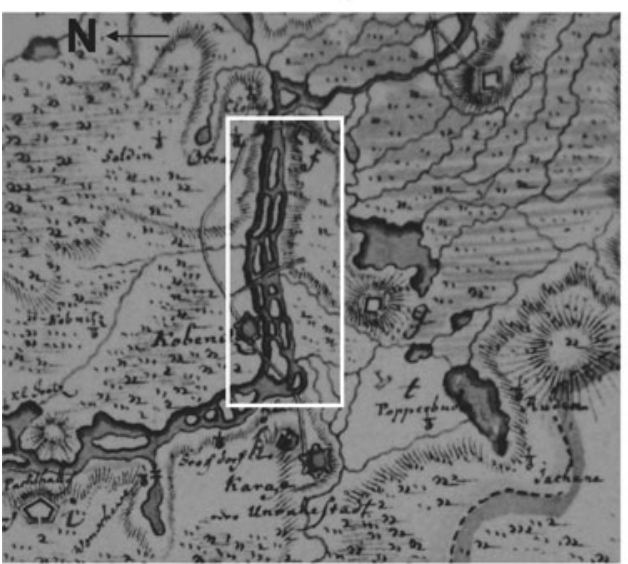

scale unknown
1793

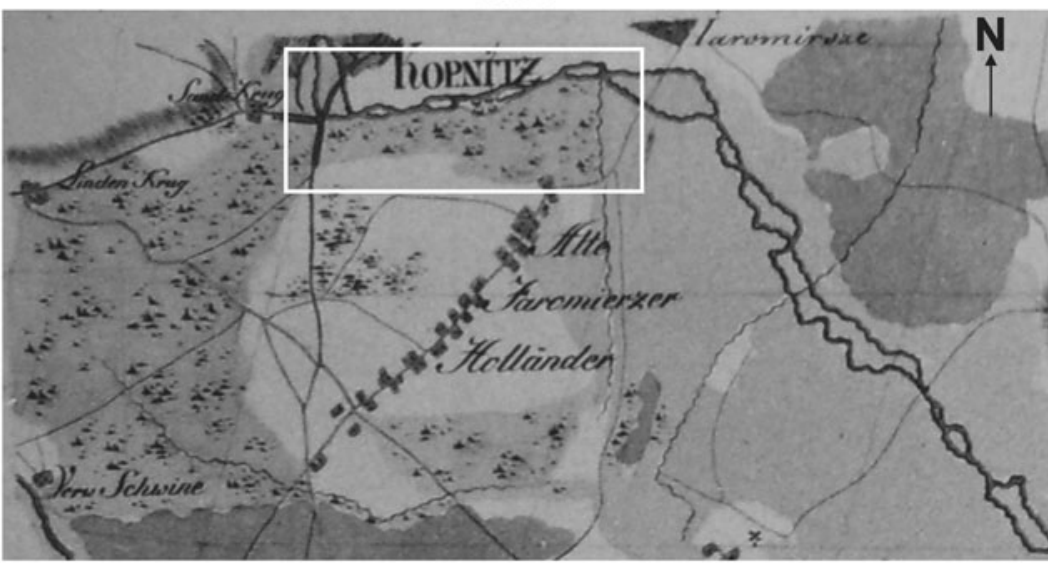

scale unknown

1828

b

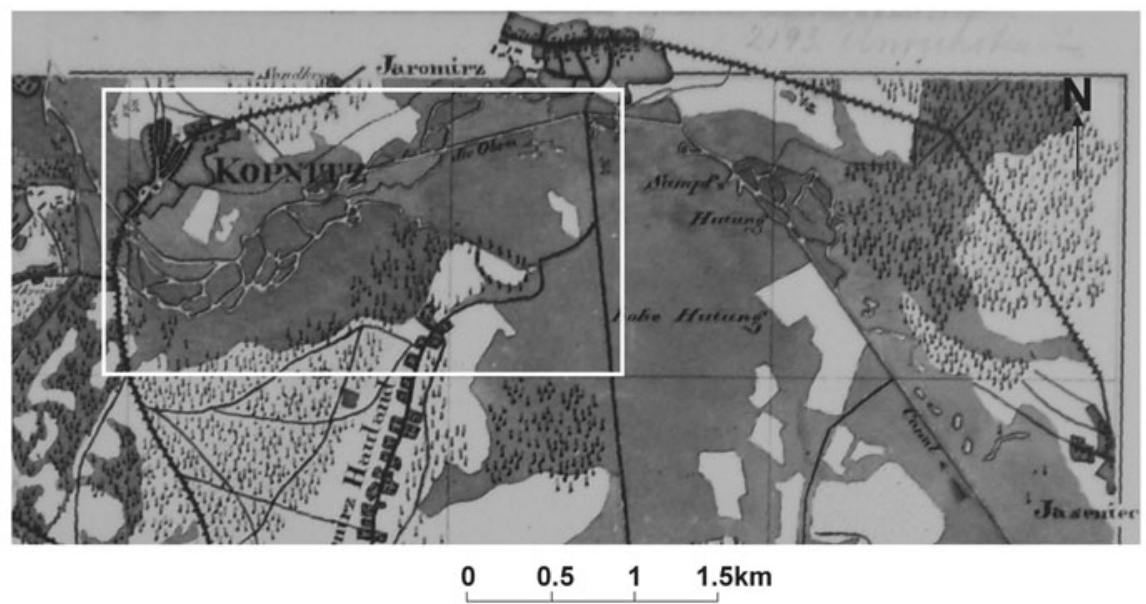

1892

c

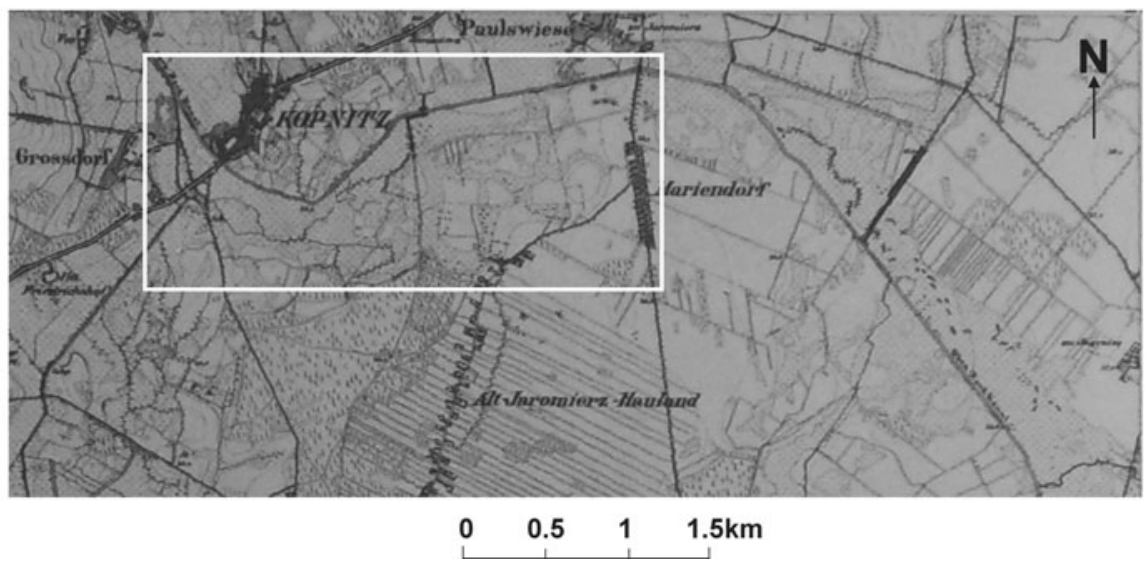

Fig. 3 Archival maps of the Obra valley near Kopanica. Detailed research area was marked with white rectangle. Note different orientation of the map from 1775

Width-to-depth $(w / d)$ ratios were calculated for distinguished traces of channels by dividing their bankfull widths by mean bankfull depths to compare the features of two retraced channel systems. Banktops of channels were identified in the GPR images to determine their bankfull widths. Mean bankfull depths were calculated by measuring the channels' depths in vertical sections spaced $2 \mathrm{~m}$ apart in the GPR images. The w/d ratios were calculated 


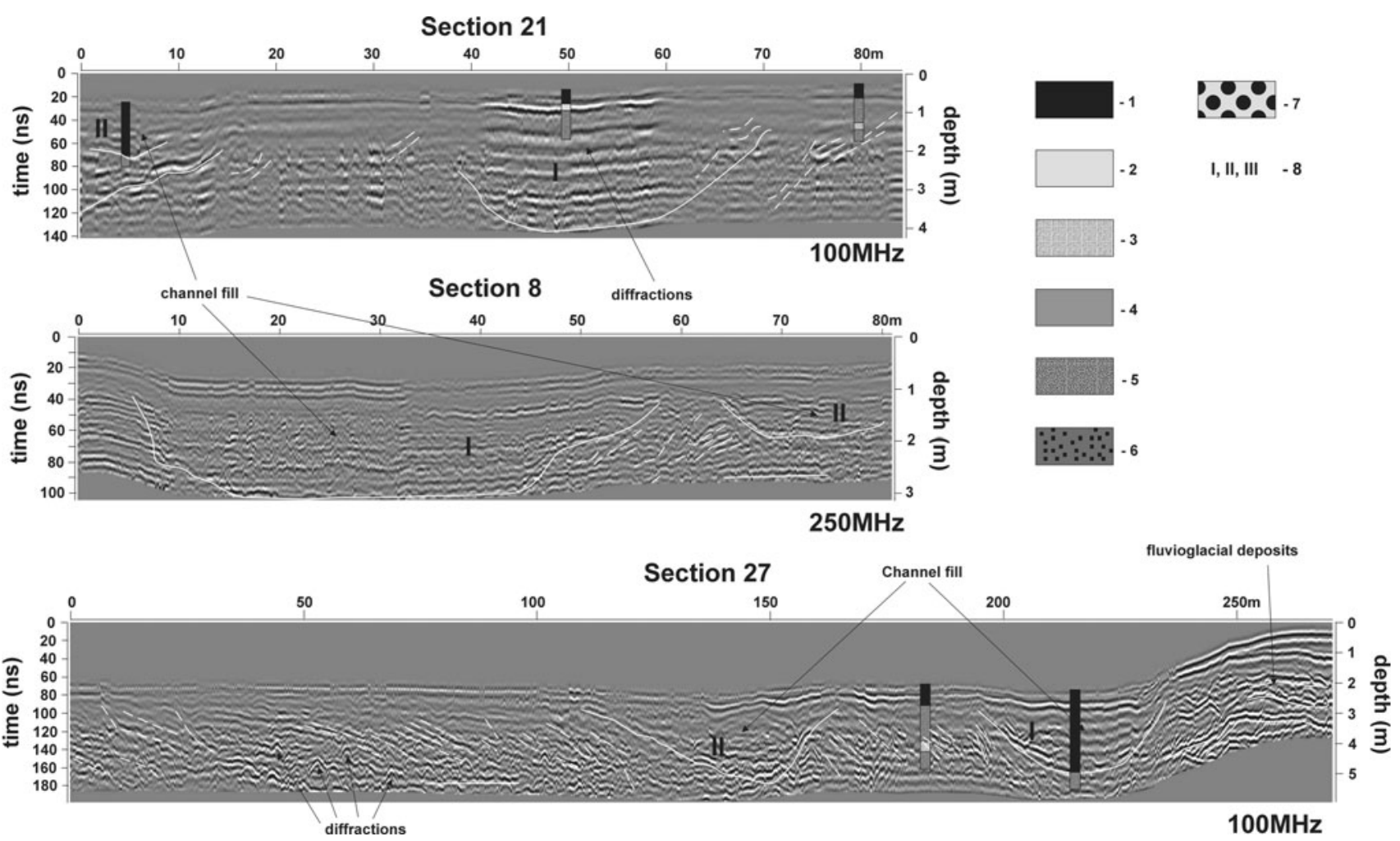

Fig. 4 Traces of a large-scale meandering pattern preserved in the floodplain deposits. Note regular dipping GPR pattern in section 27 and traces of river beds marked with concave-up reflectors in all the presented profiles. 1 -peats, 2-silts, 3-sands with inserts of silts,

for all the channels retraced in all measured (28) GPR sections.

\section{Results}

GPR reflections and core data

Types of GPR reflections were described using the examples of the sections presented in Figs. 4 and 5. A curved and concave-up GPR pattern appeared between 0 and $15 \mathrm{~m}$ of section $21,6-58 \mathrm{~m}$ of section 8 and $110-170 \mathrm{~m}$ of section 27 (Fig. 4). The reflections can also be seen in 33-66 $\mathrm{m}$ and 116-165 $\mathrm{m}$ of section 11, 20-60 m, 78-95 m and $130-175 \mathrm{~m}$ of section 14 and 5-40 m, 55-90 m, $130-160 \mathrm{~m}$ and $215-240 \mathrm{~m}$ of section 17 (Fig. 5). The reflectors appeared in all the sections within the depth range of 0.8-3.0 $\mathrm{m}$ b.l.s. (below the land surface) (Słowik 2012). The GPR signal was calibrated with core data. A concave-up pattern in $4 \mathrm{~m}$ of section 21 corresponded well to the interface between peats and fine sands indicated by coring at the depth of $1.6 \mathrm{~m}$ b.1.s. (Fig. 4). A similar consistency can be seen in $55 \mathrm{~m}$ of section 11 (concave-up pattern and peats/fine sands interface at the depth of $1.4 \mathrm{~m}$ b.1.s.; Fig. 5). In case of the coring which was conducted in 4-fine sands with organic matter, 5-fine sands, 6-medium sands, 7-coarse sands, 8-numbers of distinguished channels. Erosional surfaces and layering pattern in sand deposits were marked with continuous and broken white lines, respectively

$150 \mathrm{~m}$ of section 14 (Fig. 5), the GPR pattern was connected with the interface between fine and coarse sands (depth $1.53 \mathrm{~m}$ b.1.s.).

Numerous dipping GPR reflectors occurred in section 27, between 0 and $120 \mathrm{~m}$ and 160 and $205 \mathrm{~m}$ of the section (Fig. 5). The signal can also be seen in section 8 (50-66 $\mathrm{m}$ of the section; Fig. 4) and 17 (240-290 m; Fig. 5). Single dipping reflectors appeared in the remaining GPR sections 20, 60 and $80 \mathrm{~m}$ of section 14 (Fig. 5) and 20, 35, 66 and $80 \mathrm{~m}$ of section 21. The GPR signal occurred at the depths form 1.0 to $3.0 \mathrm{~m}$ b.l.s. The dipping pattern was correlated with sand deposits; the reflections occurred within the fine sands that can be seen in the bottom part of the core log presented in $80 \mathrm{~m}$ of section 21 (depth 1.5-1.8 m b.1.s.; Fig. 4) (Słowik 2012).

A strong horizontal georadar signal, underlain by relatively weaker horizontal reflectors, was distinguished in the top part of all of the presented sections. The distinct horizontal pattern corresponded well to the top layer of peat deposits and fine sands with organic matter that was presented in the core logs in sections 21,14 and 11 . The weaker horizontal reflectors can be connected with fine sands underlying the top layer of organic sediments. A sequence of GPR pattern changes and its connection with lithologic variability of the floodplain deposits can be clearly seen in $95 \mathrm{~m}$ of section 11 (Fig. 5). 

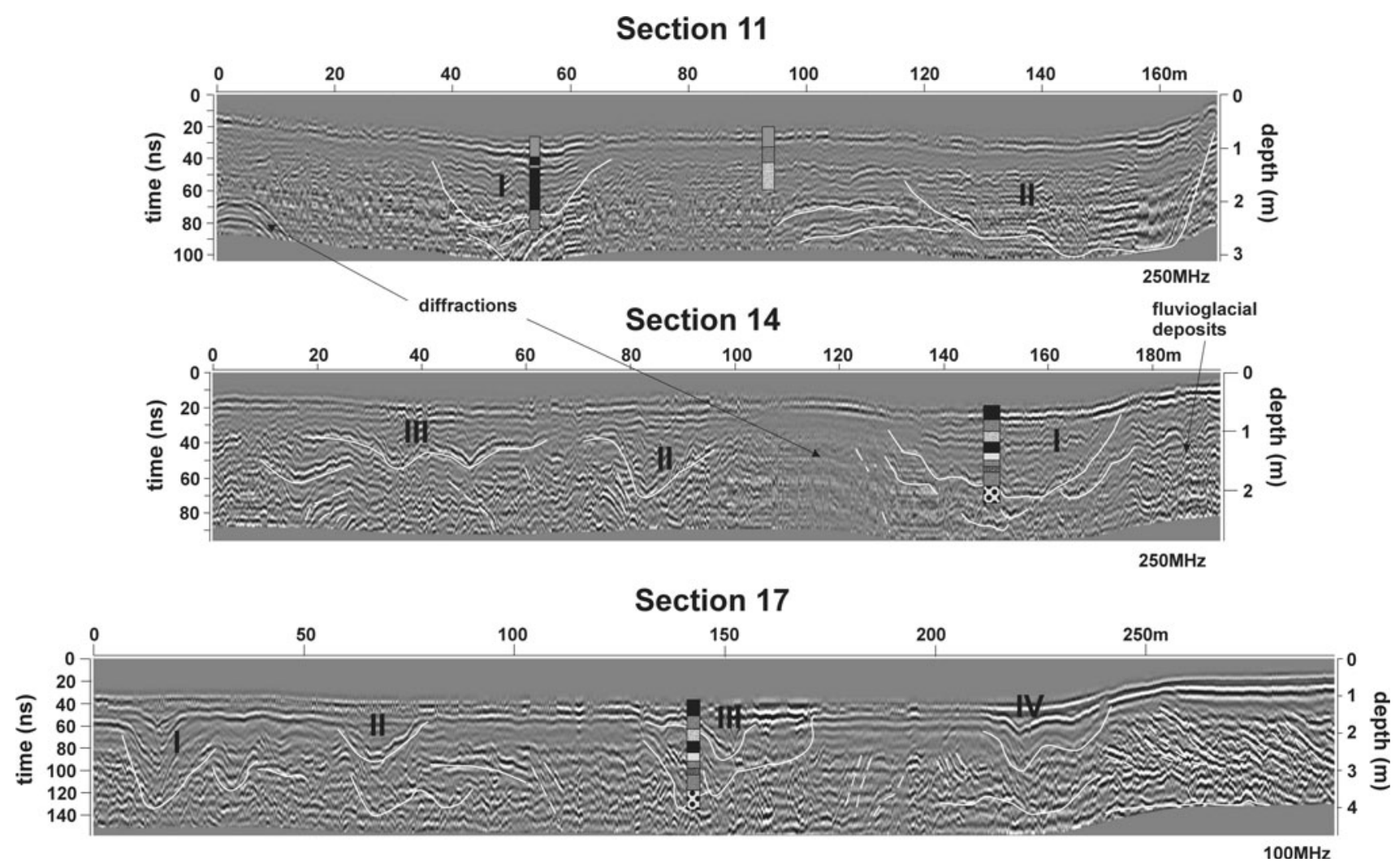

Fig. 5 Traces of a small-scale sinuous (section 11) and multi-channel pattern (sections 14 and 17). Explanations-see Fig. 4

Here, the strong horizontal pattern is connected with fine sands with organic matter in the top part of the profile; the relatively weaker reflections correspond to sand deposits (see the core $\log$ in section 11; Fig. 5). The GPR reflectors are underlain by relatively stronger subhorizontal and wavy reflectors indicating sands with inserts of silts. Similarly, situation of peats, fine sands and sands with silts is consistent with changes from strong horizontal to relatively weaker pattern and then to wavy reflectors in section 14 (core $\log$ in $150 \mathrm{~m}$ of the section; Fig. 5). Furthermore, silt deposits were correlated with a strong horizontal reflector in $50 \mathrm{~m}$ of section 21 (Fig. 4). They are underlain by fine sands corresponding to faint or lack of reflections. Moreover, the faint horizontal and slightly wavy reflectors appeared above the curved and concave-up pattern in sections 8, 27, 11 and 14 (Figs. 4, 5). The GPR reflections can be noted between 15 and $32 \mathrm{~m}$ of section 8 at the depth of $0.5-1.5 \mathrm{~m}$ b.1.s. (Fig. 4), between 230 and $280 \mathrm{~m}$ of section 27 (depth 2-3.5 m b.l.s.; Fig. 4). They can also be distinguished in $0-38 \mathrm{~m}, 70-95 \mathrm{~m}$ and $128-153 \mathrm{~m}$ of section 11 at the depth ranging from 0.7 to $2 \mathrm{~m}$ b.l.s. (Fig. 5). Similar relations between the GPR reflectors and core data were found in section 27 (Słowik 2012).

A number of diffractions were also recognized in the GPR images. They occurred in the form of hyperbolae; the largest one can be seen in $5 \mathrm{~m}$ of section 11 (Fig. 5) at the depth of $1.6 \mathrm{~m}$ b.l.s. Moreover, several small hyperbolic diffractions were noted between 45 and $110 \mathrm{~m}$ of section 27 (depth 2-3 m b.1.s.; Fig. 4). They indicate small objects buried in the floodplain deposits which are probably large clasts within sand deposits. Another disturbance obscuring quality of some of the GPR images is ringing. It appeared between 40 and $60 \mathrm{~m}$ of section 21 (Fig. 4) and between 100 and $120 \mathrm{~m}$ of section 14 (Fig. 5) as parallel continuous reflectors. It might be caused by high water content under the layer of silts presented in the core log in $50 \mathrm{~m}$ of section 21 (Fig. 4).

\section{Interpretation}

The curved, concave-up reflections accompanied with the faint subhorizontal and wavy ones can be interpreted as erosional surfaces and channel fills, respectively (Słowik 2012). Such types of GPR reflections were also presented and interpreted in a similar way by, for example, Vandenberghe and van Overmeeren (1999) and Gourry et al. (2003). Thus, traces of two river channels were distinguished in sections 21, 8, 11 and 27 and three and four channels in sections 14 and 17, respectively (Figs. 4, 5). The width of the channels varies from 20 (channel II in sections 14 and 17; Fig. 5) to $55 \mathrm{~m}$ (channel II in section 27; Fig. 4). Their maximum depths range from 1.8 (channel II, section 14; Fig. 5) to $3.0 \mathrm{~m}$ (channel II, section 17; Fig. 5) (Słowik 2012). The mean depths of the 


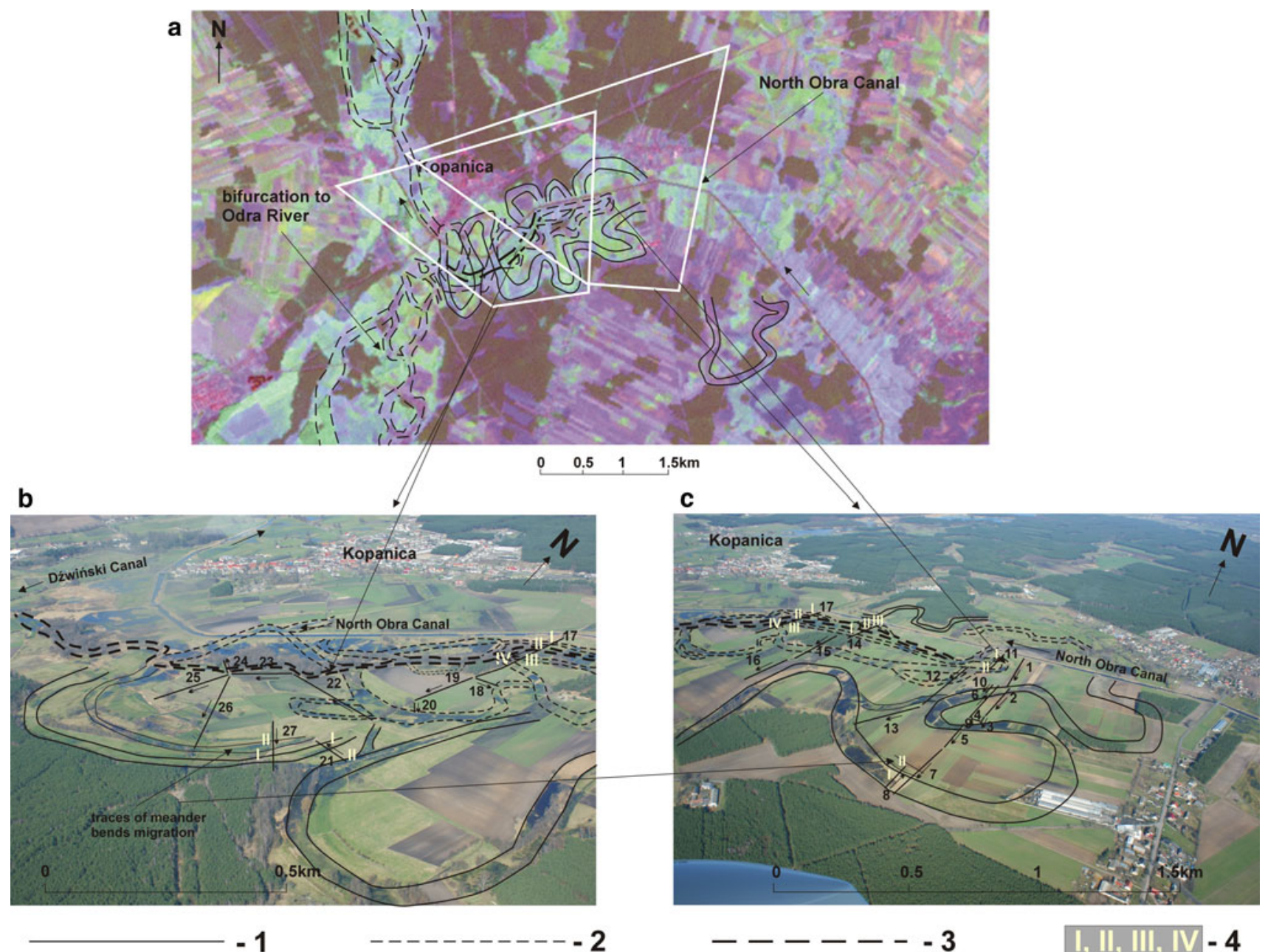

Fig. 6 LANDSAT ETM+ satellite image and oblique aerial photographs illustrating traces of former river patterns in the studied section of the valley. Traces of meander bends migration phases were marked with thin continuous lines. 1-Meandering pattern, 2-multi-channel (anastomosing) pattern, 3-traces of the main, low-sinuosity channel

channels vary from 1.2 to $2.2 \mathrm{~m}$. Erosional surfaces occurred also within an elevated part of section 27 (250-270 $\mathrm{m}$ of the section; Fig. 4). They may represent fluvioglacial deposits neighboring the studied section of the valley. Moreover, erosional surfaces appeared at the depth of $2.9-3 \mathrm{~m}$ b.l.s. in sections 17 and 27 in the form of continuous subhorizontal reflectors (Figs. 4, 5). The dipping GPR reflections mark layering pattern within sands (Słowik 2012). Such sedimentary structures were also shown by, for example, Vandenberghe and van Overmeeren (1999) and Kostic and Aigner (2007). They represent lateral accretion elements indicating development of point bars and lateral migration of a river channel (Kostic and Aigner 2007). Sands and silts represented by faint and strong subhorizontal and wavy reflections, respectively, were accumulated during flood events when the floodplain was inundated. within the multi-channel system, 4-numbers of channels, in particular GPR sections distinguished in Figs. 4 and 5. The area presented in aerial photos was marked in the satellite images with white lines

Traces of former Obra channels were also inferred from the satellite image (Fig. 6a). They were marked in the image with light violet and dark green. Light green indicated agricultural areas with vegetation and dark violet ploughed fields. The light green areas illustrate the width of the Obra valley as well as the bifurcation to the Odra River (Fig. 6a). Forests were marked with dark green and villages with light red. It should be noted that delimitation of the river patterns was limited here by the resolution of the satellite image which amounted $15 \mathrm{~m}$ after applying a pansharpening option.

\section{Discussion}

The following sequence of the Obra River pattern changes may be proposed in the light of the conducted research: 
1. A large-scale meandering pattern featured with w/d ratios from 15 to 40 . The pattern formed the actual width of the valley alluvial fill reaching $1.6 \mathrm{~km}$.

2. A transition from the meandering to a multi-channel pattern of w/d ratio ranging from 11 to 22 . The multichannel pattern had been still functioning in the eighteenth century before the anthropogenic alteration of the river course (Fig. 3a).

3. Anthropogenic transformation of the multi-channel pattern into the North Obra Canal.

\section{Meandering pattern}

Distinct traces of palaeomeanders were noted in the aerial images (Fig. 6). Their situation corresponds to the erosional surfaces and channel fills shown in Fig. 4. The meandering channels are characterized by w/d ratios from 15 to 40 in all the sections describing the channel pattern (e.g., section 27). According to a classification of natural rivers proposed by Rosgen (1994), the traces of the meandering pattern belong to stream type $\mathrm{C}$ (low gradient, meandering, point bar, riffle/pool alluvial channels with broad, well-defined floodplain characterized by w/d ratio $>12$ and sinuosity $>1.4$ ) (Słowik 2012). Rosgen (1994) described this type of river patterns as formed in broad valleys characterized by well-defined meander bends. The description matches the studied section of the Obra valley and distinct traces of palaeomeanders that can be distinguished in the satellite and aerial photographs (Fig. 6).

The dipping GPR pattern (sections 8 and 27; Fig. 4 and the elevated part of section 17; Fig. 5) records a continuous lateral migration of the meander bends. The dipping signal is underlain by continuous subhorizontal reflections that were interpreted as erosional surfaces (Fig. 4). The reflectors may be the traces of an erosive unconformity separating the meandering pattern from an earlier period of the valley development. A similar erosive boundary between lateral accretion elements (meandering pattern) underlain by scour fills (braided pattern) was detected by Kostic and Aigner (2007). However, recognition of deeper parts of the Obra floodplain deposits is needed to find evidence for such transition. Traces of two channels were distinguished in the sections presented in Fig. 4. The channels that can be seen between 110 and $165 \mathrm{~m}$ of section 27 and between 63 and $81 \mathrm{~m}$ of section 8 can be interpreted as records of migration phases of the palaeochannels (Figs. 4, 6b, c). Migration phases of meander bends were recognized by Słowik (2011b) in the lower course of the Obra River. The preserved traces might have been the effect of a period featured with long-lasting high water stages and/or frequent flood events. A lateral, stagnant water channel might have been formed in such conditions, in the vicinity of an active river bed (Słowik et al. 2010; Słowik 2011b).

\section{Multi-channel pattern}

Traces of two, three and four channels were distinguished in sections 11, 14 and 17, respectively (Fig. 5). They are characterized by $w / d$ ratios ranging from 11 to 22 . Dipping GPR reflections marked a lateral accretion pattern; however, changes of the direction of dipping can be observed. The erosional surfaces marking the channels are situated at different elevations (Fig. 5). This may have been caused by a various degree of eroding and reworking the channels. This suggests changes of direction of the lateral migration of the channels. A multi-channel pattern may have been functioning in the area of the valley situated close to the North Obra Canal (Fig. 6). The remains of the channels are situated at a lower level of the valley floor than the palaeomeanders (see section 17 in Fig. 5). It means that the river bed incised into the valley floor during the transformation (Słowik 2012). The pattern can be classified as type DA according to the classification of Rosgen (1994). He described such a river pattern as anastomosing (multiple) with narrow and deep channels ( $w / d$ ratio $<40)$, well-vegetated floodplain and associated wetlands, variable sinuosity and stable streambanks.

The distinguished channels have some features of an anastomosing river. Smith (1983) presented core logs illustrating silts and muds as dominant elements of anastomosing river architecture. Such deposits are also present in the Obra valley alluvial fill (see core logs in Fig. 5). It can be suggested that the system of the channels was stable. Except for the cohesive deposits, the stability of the streambanks may have been influenced by a dense vegetation cover and wetlands. Before the period of the hydrotechnical works, the Obra valley was an enormous wetland which can be seen in the archival maps presented by Słowik (2011a) (see also the map from 1775; Fig. 3a). Furthermore, the pattern is similar to the Columbia River planform studied by Makaske et al. (2009). The main, lowsinuosity channel (Fig. 6) is accompanied here by a number of secondary channels. The channel is marked with dark green in the satellite image (Fig. 6a), and an elongated pool overgrown with alder trees in the aerial photos (Fig. 6b, c). The w/d ratios of the Obra and Columbia River (from 9 to 23; Makaske et al. 2009) are comparable (Słowik 2012). Makaske (2001) stated that straight channels may occur in a combination with anastomosis.

River patterns of many lowland rivers have been altered from braided to meandering due to the Holocene climatic changes (e.g., Kozarski and Rotnicki 1978; Starkel 2001; Leigh 2006) and/or anthropogenic intervention (Matys 
Grygar et al. 2011). An opposite transition (from a meandering to multi-channel planform) was recognized in the studied course of the Obra River. The transformation from meandering to anastomosing pattern was suggested by Gradziński et al. (2003) in the case of the Narew River. Moreover, they stated that some of meandering sections are still active within the modern anastomosing pattern. A similar situation may have taken place in the Obra valley; distinct traces of a relatively small-scale meander (section 11; Fig. 5, see also Fig. 6) were classified here as belonging to the multi-channel pattern.

A series of large floods followed by channel aggradation causing avulsions may have caused the transformation of the river planform (Słowik 2012). However, the character and timing of such processes require further studies. The multi-channel pattern was transformed into the North Obra Canal in the beginning of the nineteenth century. The maps from 1828 and 1894 illustrate the process of accumulation of organic deposits in the remains of the channels (Fig. 3b, c). The land use was also altered; wetted meadows were replaced with agricultural areas (see the archival maps and satellite image in Figs. 3, 6, respectively).

\section{Implications for river restoration}

Two types of natural river patterns have been distinguished within the studied section of the Obra valley. The main question is which river pattern is to be restored?

Determining condition of a given river course must be determined in relation to a reference point (Cairns 1989 in: Brierley et al. 2002). In the studied case, the state of the Obra River in the eighteenth century (Fig. 3a) that preceded the anthropogenic alteration of the river course was recognized as the reference condition. It may be described as "close to natural." In terms of geomorphic recovery (Brierley et al. 2002) the Obra River is in a poor condition; after constructing the North Obra Canal (stage C and D; Fig. 7) the river system is not able to go back to its "natural" structure. According to the River Styles framework (Brierley et al. 2002) the site near Kopanica belongs to alluvial settings with absent natural channel.

Reconstructing the large-scale meandering planform would be difficult to conduct due to a long path of changes that took place after its functioning (Fig. 7). Natural factors influencing changes of the river pattern in stage A and B were possibly prevailing (possibly series of large floods, river bed incision), although an anthropogenic influence cannot be excluded here; riparian peatlands served for clear-cutting and hay making since the Iron age (Schwaar 1990 in: Jensen et al. 2006). Embankments and dikes were constructed along river courses in Medieval times (Jensen et al. 2006). The first water mills in the Middle Obra valley were built in the twelfth century (Kaniecki and Brychcy
2010). Since the beginning of the nineteenth century, the anthropogenic influence became dominant-the multichannel planform was replaced with the North Obra Canal (Fig. 7; stage C and D).

It is proposed to restore the multi-channel section of the Obra valley that was active in 1828 (see the map in Fig. 3a) The restoration regards the river channels as well as the floodplain with wetlands and riverine meadows. A restoration path to such a target point was shown in Fig. 7. As the anthropogenic changes of the Obra pattern are irreversible, the planned reconstruction of the Obra pattern would be, in terms defined by Brierley et al. (2002), a "created river condition." Two possible scenarios of the creation may be proposed. The first one is to reconstruct the entire multi-channel pattern (stage F; Fig. 7) and the other to restore the main, low-sinuosity channel that was retraced in the aerial photos and satellite image (see Fig. 6 and stage F1 in Fig. 7). Here, the main question is whether the river, having recreated the main channel, would be able to self-adjust and "activate" the remaining channels. Geologic surveys showed that the channels are filled with organic deposits, silts and silty sands. The sediments are resistant to erosion so, possibly, a high-magnitude flood event (or a series of floods) would be needed to have caused such reaction of the river. It would be difficult to control such an intensive flood, and its consequences would be hard to predict. Thus, stage F1 (Fig. 7) seems to be more realistic.

A number of studies (e.g., Makaske 2001; Gradziński et al. 2003) showed that in-channel and floodplain aggradation have an important influence on evolution of anastomosing rivers. Thus, the created system would be permitted to evaluate as aggradation occurs. When a significant erosion prevails, for example, tending to alter the river planform toward meandering, interventions aiming to maintain the restored multi-channel pattern should take place. Such involvement in processes forming river bed was applied, for example, in a restored course of the Clark Fork River where avulsion cutoffs formed by an intensive flood were refilled with sediment (Woelfle-Erskine et al. 2012). The restoration of the Obra River should lead to creation of a relatively stable floodplain that would allow development of ecotourism as well as wildlife and fish preservation. Jacobson and Galat (2006) proposed a rehabilitation project of the Missouri River aiming to reconstruct its historical, multi-channel course from 1894. They found out that a spatial extent of shallow water areas was greater in the historical than in the modern channel which was favorable for fish and plant species. Possibly, this might also have been the case of the Obra River. A varying distribution of the elevations of the retraced Obra channels (Fig. 5) may suggest a more frequent occurrence of shallow water conditions in comparison with the modern artificial canal. 


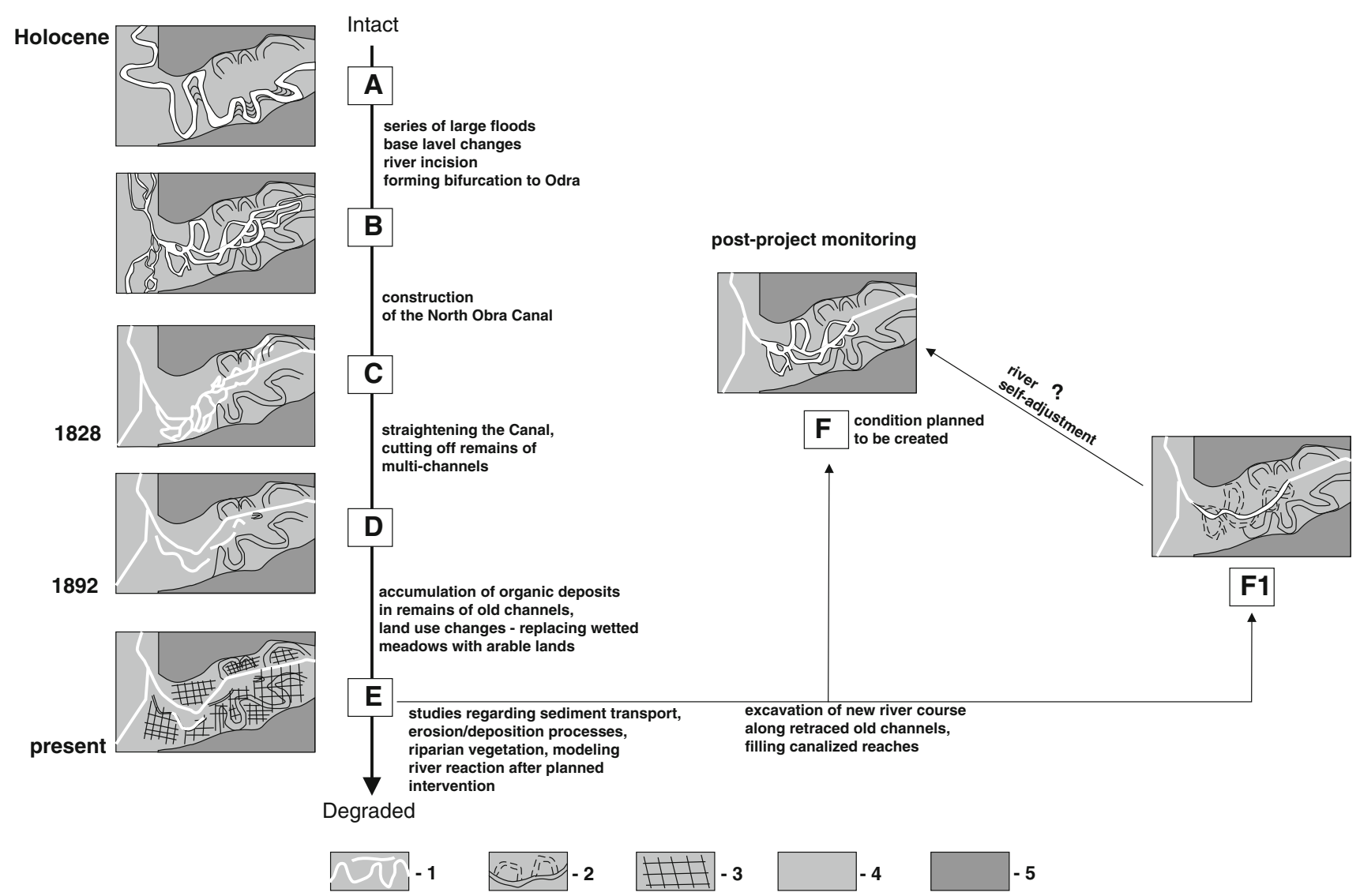

Fig. 7 A schematic path of transformations of the Obra River pattern with proposed possibility of restoration. The concept is based on the recover potential framework of Brierley et al. (2002). A-highly sinuous meandering river with w/d ratio $25-40, B$-network of simultaneously functioning channels indicating features of anastomosing pattern $($ w/d ratio $=11-22), C$-state after construction of the North Obra Canal which is connected with active network of channels south of Kopanica (see also the map from 1828 in Fig. 3). Canalizing bifurcation to Warta (construction of the Dżwina Canal).

Another question arising from the proposed river restoration is what would be lost if the conditions from the first half of the nineteenth century are restored? The main goal of the construction works was to lower the groundwater level to $20 \mathrm{~cm}$ below the land surface (Schütze 1914) and to turn the Obra wetlands into an agricultural area. The canals provided water conveyance through the area of the Middle Obra valley. In the case of the river restoration, the water transfer near the study site would stop functioning and the restored area would be more frequently flooded. However, the studied area is regularly inundated anyway due to high groundwater levels in spring months. As a result, fields localized in the depressions of the valley floor are inundated. It was observed during the field surveys that local farmers tried to cover the depressions with sand to elevate the land surface and avoid the inundation. Moreover, flooding would be needed after the restoration to allow the river to self-adjust.
$D$-straightening of the Obra Canal and cutting off remains of the former channels. $E$-deposition of organic material in remains of river channels, land use changes-wetted meadows transformed into arable lands. $F$-scenario I: excavating retraced network of channels and creating river conditions similar to those from 1828 (stage C), F1-scenario II: excavating the main, low-sinuosity channel and further river self-adjustment to stage F. 1-active channels, 2remains of former channels, 3-floodplain with agricultural areas, 4-area of floodplain, 5-areas surrounding river valley

\section{River restoration and river history}

According to Downs and Thorne (2000) river restoration can be defined as a historically influenced exercise in environmental enhancement through morphological modification. This means that a historical analysis of a river pattern as well as field surveys are crucial before attempting to restore a river course. It is obligatory to understand how a river behaves or behaved in a given valley setting (Brierley et al. 2002). Woelfle-Erskine et al. (2012) noted that river restoration projects are not always based on data referring to reference conditions that preceded a given disturbance. They reported findings of Montgomery (2008) who noted that a sinuous or meandering course is often being restored even when such a river pattern was not present in the history of a given river course. A construction of a river channel different from natural geomorphic conditions may lead to failure or 
reduced ecological benefit (Woelfle-Erskine et al. 2012). They also stated that multi-channel patterns can be treated as reference conditions in many alluvial rivers. The presented case of the Middle Obra valley confirms their notions.

This study underlines the need to recognize the history of a river system before undertaking any restoration works. It also shows the application of complementary geological, geophysical and remote sensing methods to study the evolution of a river system. Basing only on the aerial and satellite images (Fig. 2), a restoration of the large-scale meandering pattern would seem to be a rational decision. However, the meander bends belonged to an ancient river system functioning in discharge and sediment supply conditions that were different from these forming the anastomosing system. Such conditions are impossible to be reconstructed today owing to a long path of changes from the meandering planform to the present state (Fig. 7). This is why the river course proposed for restoration should correspond to the historical multi-channel pattern.

It should be noted that the paper shows only a geologic and geomorphologic background that is needed for river restoration. A significant input form other nature specialists (e.g., biologists, biogeographers, economists) is needed to further develop this idea.

\section{Conclusions}

Geologic, geophysical and remote sensing surveys enabled to retrace a sequence of changes of the Obra river pattern. Two types of the river planform were distinguished: a largescale meandering and multi-channel indicating features of an anastomosing river course. The transformation from the meandering to multi-channel pattern might have been caused by series of large floods followed by in-channel aggradation and avulsions. Next, the network of channels was replaced with an artificial canal. As a result, remains of the natural channels were filled with organic deposits and overgrown. Traces of both river patterns were preserved in the modern land surface in the form of palaeomeanders and elongated depressions and ponds. The land use of the studied section of the valley was also altered; wetted meadows were replaced with agricultural areas.

The studied reach of the Obra River is not able to selfadjust to the conditions from the period preceding the hydrotechnical works. On the basis of the conducted research, it was proposed to create the river course from 1828 when the multi-channel pattern was still active. Such intervention would also influence restoration of the floodplain vegetation and might stimulate development of ecotourism in the middle course of the river. This study shows that the analysis of a river course history and evolution is crucial before attempting any restoration works. This is mandatory that a restored river pattern should correspond to the conditions that were present in the past in a given river system.

Acknowledgments The results presented in this paper are a part of a research program "Determining changes of river bed pattern in the middle course of the Obra Valley using analysis of satellite and aerial images, and GPR (ground-penetrating radar) method" supported by the National Science Centre Grant No 2011/01/B/ST10/04930. MSc Remigiusz Tritt and MSc Jacek Cieślewicz are acknowledged for their great help during field surveys. The Editor-in-Chief, Wolfgang Cramer, and two anonymous reviewers are appreciated for their valuable comments to improve this manuscript.

Open Access This article is distributed under the terms of the Creative Commons Attribution License which permits any use, distribution, and reproduction in any medium, provided the original author(s) and the source are credited.

\section{References}

Babek O, Hilscherova K, Nehyba S, Zeman J, Famera M, Francu J, Holoubek I, Machat J, Klanova J (2008) Contamination history of suspended river sediments accumulated in oxbow lakes over the last 25 years. J Soil Sed 8:165-176

Best J, Woodward J, Ashworth P, Smith GS, Simpson Ch (2006) Bartop hollows: a new element in the architecture of sandy braided rivers. Sed Geol 190:241-255

Brierley G, Fryirs K, Outhet D, Massey C (2002) Application of the river styles framework as a basis for river management in New South Wales, Australia. Appl Geogr 22:91-122

Cairns J (1989) Restoring damaged ecosystems: is predisturbance condition a viable option? Environ Prof 11:152-159

Downs PW, Thorne CR (2000) Rehabilitation of a lowland river: reconciling flood defense with habitat diversity and geomorphological sustainability. J Environ Manage 58:249-268

Dynowska J (1972) Typy reżimów rzecznych w Polsce. Zesz. Nauk. UJ CCXVIII Prace Geogr 28:1-155 (In Polish)

Gingrich S, Haidvogl G, Krausmann F (2011) The Danube and Vienna: urban resource use, transport and land use 1800-1910. Reg Environ Change. doi:10.1007/s10113-010-0201-x

Gordon E, Meetenmeyer RK (2006) Effects of dam operation and land use on stream channel morphology and riparian vegetation. Geomorphology 82:412-429

Gourry J-Ch, Vermeersch F, Garcin M, Giot D (2003) Contribution of geophysics to the study of alluvial deposits: a case study in the Val d'Avaray area of the river Loire, France. J Appl Geophys 54:35-49

Gradziński R, Baryła J, Doktor M, Gmur D, Gradziński M, Kędzior A, Paszkowski M, Soja R, Zieliński T, Żurek S (2003) Vegetation-controlled modern anastomosing system of the upper Narew River (NE Poland) and its sediments. Sed Geol 157:253-276

Hoffmann T, Thorndycraft VR, Brown AG, Coulthard TJ, Damnati B, Kale VS, Middelkoop H, Notebaert B, Walling DE (2010) Human impact on fluvial regimes and sediment flux during the Holocene: review and future research agenda. Glob Planet Change 72:87-98

Jacobson RB, Galat DL (2006) Flow and form in rehabilitation of large-river ecosystems: an example from the lower Missouri River. Geomorphology 77:249-269 
Jensen K, Trepel M, Merritt D, Rosenthal G (2006) Restoration ecology of river valleys. Basic Appl Ecol 7:383-387

Kaniecki A (2004) Poznań: dzieje miasta wodą pisane (Summary in English: Poznań: the history of the city written with water). Wydawnictwo PTPN, Poznań

Kaniecki A, Brychcy D (2010) Średniowieczne młyny wodne i ich wpływ na przemiany stosunków wodnych na przykładzie zlewni Obry Skwierzyńskiej (Summary in English: Medieval water mills and their influence on water relationships alteration on the basis of Obra Skwierzyńska Catchment). Badania Fizjograficzne Seria A-Geografia Fizyczna A61:145-156

Kostic B, Aigner T (2007) Sedimentary architecture and 3D groundpenetrating radar analysis of gravelly meandering river deposits (Neckar Valley, SW Germany). Sedimentology 54:789-808

Kozarski S, Rotnicki K (1978) Problemy późnowurmskiego i holoceńskiego rozwoju den dolinnych na niżu Polskim (Summary in English: Problems concerning the development of valley floors during late-Würm and Holocene in the Polish lowland). Prace Komisji Geograficzno-Geologicznej PTPN 19:1-1-57

Large AR, Petts GE (1996) Historical channel-floodplain dynamics along the River Trent. Appl Geogr 16:191-209

Leigh DS (2006) Terminal Pleistocene braided to meandering transition in rivers of the Southeastern USA. Catena 66:155-160

Makaske B (2001) Anastomosing rivers: a review of their classification, origin and sedimentary products. Earth Sci Rev 53:149-196

Makaske B, Smith DG, Berendsen HJA, de Boer AG, van NielenKiezebrink MF, Locking T (2009) Hydraulic and sedimentary processes causing anastomosing morphology of the upper Columbia River, British Columbia, Canada. Geomorphology 111:194-205

Matys Grygar T, Novakova T, Mihaljevic M, Strnad L, Svetlik I, Koptikova L, Lisa L, Brazdil R, Macka Z, Strachon Z, Svitavska-Svobodova H, Wraz DS (2011) Surprisingly small increase of sedimentation rate in the floodplain of Morava River in the Straznice area, Czech Republic, in the last 1300 years. Catena 86:192-207

Montgomery DR (2008) Dreams of natural streams. Science 319: 291-292

Multan M (2003) Objaśnienia do szczegółowej mapy geologicznej Polski 1:50 000. Arkusz Kargowa (in Polish). Warszawa:1-30

Neal A (2004) Ground-penetrating radar and its use in sedimentology: principles, problems and progress. Earth-Sci Rev 66:261-330

Rosgen DL (1994) A classification of natural rivers. Catena 22:169-199
Schwaar J (1990) Natur und Vergangenheit. Bremen und sein Umland in den letzten Jahrhunderten. Abhandlungen des Naturwissenschaftlichen Vereins Bremen 41:49-86

Schütze H (1914) Landeskunde der Provinz Posen. Wrocław

Skelly RL, Bristow ChS, Ethridge FG (2003) Architecture of channelbelt deposits in an aggrading shallow sandbed braided river: the lower Niobrara river, northeast Nebraska. Sed Geol 158:249-270

Słowik M (2011a) Changes of river bed pattern and traces of anthropogenic intervention: the example of using GPR method (the Obra River, western Poland). Appl Geogr 31:784-799

Słowik M (2011b) Reconstructing migration phases of meandering channels by means of ground-penetrating radar (GPR): the case of the Obra River, Poland. J Soil Sediment 11:1262-1278

Słowik M (2012) Anthropogenic transformation of lowland river pattern and changes of spatial extent of lakes inferred from ground-penetrating radar and remote sensing surveys (the Obra River, Poland). In: Liu L, Sato M, Xie X, Kong F, Zhao Y (eds) Proceedings of the 14th International Conference on ground penetrating radar, Shanghai, China, 4-8 June 2012 Volume III:743-748

Słowik M (2013) GPR and aerial imageries to identify the recent historical course of the Obra River and changes of spatial extent of Obrzańskie Lake, altered by hydro-technical works. Environ Earth Sci. doi:10.1007/s12665-012-2215-9

Słowik M, Sobczyński T, Młynarczyk Z (2010) Types of sedimentary environment in alluvial sediments distinguished on the basis of its chemical constitution: the example of the lower course of the Obra river (Western Poland). Environ Earth Sci 59:957-966

Smith DG (1983) Anastomosed fluvial deposits: modern examples from western Canada. In: Lewin J, Collinson JD (eds) Modern and ancient fluvial systems. Wiley, New York, pp 155-169 Special Publication No. 6 of the International Association of Sedimentologists

Starkel L (2001) Historia doliny Wisły od ostatniego zlodowacenia do dziś (Summary in English: Evolution of the Vistula river valley since the last glaciation till present). PAN, Instytut Geografii I Przestrzennego Zagospodarowania, Monografie 2:1-262

Vandenberghe J, van Overmeeren RA (1999) Ground penetrating radar images of selected fluvial deposits in the Netherlands. Sed Geol 128:245-270

Woelfle-Erskine C, Wilcox AC, Moore JN (2012) Combining historical and process perspectives to infer ranges of geomorphic variability and inform river restoration in a wandering gravelbed river. Earth Surf Proc Land 37:1302-1312 